\title{
Agriculture in Taiwan and South Korea: the minimalist state? ${ }^{1}$
}

\author{
Mick Moore
}

\section{Introduction}

As is discussed elsewhere in this Bulletin issue, the degree of state involvement in economic decisionmaking in Taiwan and South Korea has been understated by adherents of the economic doctrines of laisser faire. This debate about the extent of state intervention has focused mainly on the industrial sector. The proponents of laisser faire have been unable to garner much support for their interpretations of the Taiwanese and Korean experiences from the policies practised towards agriculture. For the high degree of state intervention in the agricultural economy has been well documented. This is especially true of Taiwan, where relatively fast agricultural growth since the 1940 s is widely attributed to activist public policy [eg Johnston and Clark 1982]. Lee [1971] in particular has detailed how in the early stages of Taiwan's rapid post-war growth, the state extracted from agriculture a large volume of material resources (finance, food, labour and exports) to support industrialisation. The main mechanisms used were: obligatory rice deliveries from all paddy farmers at low prices; monopoly control over fertiliser supply, sugar cane processing and foreign trade in the major agricultural commodities; and a quasi monopoly of the foodgrain trade. Monopoly state control of foreign trade in foodgrains and of agricultural input supply, and widespread official coercion (in the 1970s) to influence farmers' production practices have been documented for Korea [Aqua 1974; Ban et al 1980; Brandt 1977; Reed 1979; Wade 1982, 1983].

Is agriculture in some way a special case? Do the extent and consequences of substantial state intervention in agriculture have little or no bearing on the debates about the actual, feasible and desirable degrees of public regulation of the economy as a whole? This article argues that this is not so. It indicates three conclusions about the relationship of the state to the

1 The author is grateful to Robert wade and Gordon white for comments on an earlier draft of the paper. For reasons of space, no references or details are given when making points about changes in economic structure.

IDS Bullerin. 1984. vol 15 no 2. Institute of Development Studies. Sussex agricultural economy in Taiwan and Korea since the early 1950 s:

i) That in the early stages of industrialisation state action which considerably 'distorted' price ratios affecting agriculture played an even more important positive role in promoting agricultural growth than is implied by examining the transfer of resources from agriculture to industry. This intervention also helped to provide an appropriate supply of the 'right' kind of industrial labour, and to maintain the political quiescence of the rural population.

ii) That even in countries like Taiwan and South Korea where senior bureaucrats and politicians making economic decisions are to a relatively high degree insulated from direct political pressures to alleviate the material conditions of large population groups [Hofheinz and Calder 1982], changes in economic structure generate strong political pressures for the state to intervene in the economy in new ways.

iii) That market forces alone often cannot achieve the kinds of economic restructuring which is required to adjust to, and facilitate further, rapid economic growth.

These three conclusions have two broad implications for the debate about the relative roles of public action and free markets in the economy generally. One is that state action in apparent violation of market principles can play a very positive role in promoting economic growth. The other is that political and economic imperatives may make high levels of state involvement in economic decision-making practically unavoidable.

\section{Agriculture and Industrial Growth in the 1950s and 1960s}

After the land reforms of the late 1940s and early 1950s [Thorbecke 1979:172-6; Ban et al 1980:ch 10] the agrarian systems of Taiwan and South Korea were remarkably similar. Their main features were: the predominance of small family farms averaging about 
one hect are; the dearth of large farmers, landlords and landless agricultural labourers; the dominance in the cropping pattern of rice, which was grown by most farmers; a high degree of dependence of agricultural production on current inputs supplied from within the family farm, notably labour and organic fertiliser; the limited role of fixed capital other than land and publicly owned and managed gravity flow irrigation facilities; and the prime reliance of farm families on agriculture as a source of income, with nonagriculture providing about 20 per cent. ${ }^{2}$

The structure of the agricultural economy made farmers relatively easy prey for sets of policies which subordinated agriculture to the goals of industrialisation and strengthening the state in relation to its external enemies and potential internal opponents. In the 1950s and 1960s agriculture contributed to these goals in three ways.

In the first place, policies to depress agriculture's terms of trade extracted significant surpluses of a) cheap food which lowered industrial wages and thus production costs; b) financial resources; and c), in the Taiwanese case, agricultural exports, to fuel industrialisation. As is mentioned above, in Taiwan this objective required high levels of direct state control of foreign trade, sugar cane processing, foodgrain marketing and agricultural input supply and output procurement. Korea by contrast was and remains in substantial food deficit. The primary mechanism for the exploitation of agriculture was to deny it the protection awarded industry and to import large quantities of foodgrains, often on concessional terms. Compared to Taiwan, state agencies did not intervene very directly in the domestic agricultural economy, and indeed to a large extent ignored it [Kim and Jhoo 1982; Ban et al 1980].

In the second place, adverse terms of trade for agriculture ensured a continual flow of new applicants to the industrial labour force. Since these migrants came largely from farm families - rather than landless households - they maintained rights and connections in the rural areas which inhibited the formation of proletarian consciousness in the urban and industrial environment. The demographic characteristics of the applicants for industrial jobs add weight to this point. Married males tended to stay on the farm. Industrial employers were able to recruit younger males and females. The latter in particular

\footnotetext{
- A few significant differences might be noted: after the repair of the damage and dislocations caused by Second World War, the Korean War, and the descent of the Chimese Nationalists upon Taiwan, Taiwan re-emerged with an export surplus of rice and sugar while Korea, having been a rice exporter under the Japanese, became and remains a substantial cereal importer; there was more inequality within the Taiwanese farm sector than in Korea; rural communications and infrastructure were much better in Taiwan than in Korea.
}

tended to see themselves only as temporary members of the ind ustrial workforce, and were correspondingly particularly unlikely to organise politically. Labour turnover was often high, and this proved especially convenient for employers during industrial recessions, when the small farm sector served as a temporary refuge for those who would otherwise have expected non-agricultural jobs. Equally, rapid labour turnover and the inability of the labour force to assert claims to permanent employment made it especially easy for industrialists to respond quickly to changes in market opportunities and switch product lines.

In the third place, a rural economy comprising mainly small family farmers found it especially difficult to organise politically to oppose the anti-agriculture bias of economic policy. This not only made it easier to pursue this policy, but helped to prevent the emergence of political conflict and instability which would have frightened domestic and foreign industrial investors.

In the Korean case rural political instability was less of a threat in the 1950s and 1960s because land reform and the events surrounding the Korean war had largely ameliorated or eliminated the rural radicalism, especially anti-landlordism, which had been so prominent in the late 1940s.

In Taiwan the threat was more real, especially because of the danger of the fusion of farmers' occupational grievances with the resentments of the mainly agricultural Taiwanese population against Mainlander Nationalist rule. An important aspect of the response of the ruling Kuomintang, both in rural and urban areas, was what might be termed 'political gap-filling': the creation, under state and ultimately party sponsorship, and 'guidance', of monopoly organisations to fill, in a formal sense, every possible need. This was closely allied with a) the attempt, largely successful in a formal sense at least, to make the KMT itself into a mass party and to induct into it those who emerged as leaders in any sphere of activity; b) the close monitoring of religious institutions and sects, which cannot be formally incorporated into civic associations, and which, because of the strong ties of religion with locality and community in Taiwan, have a potential political dimension; and c) the establishment, albeit originally very reluctantly and under considerable direct and indirect American pressure, of a facade of extreme democracy: endless elections (Taiwanese probably vote more often than almost any other people in the world) to territorial government at all levels (village, township, county, province, China) and to 'civic associations', notably, in rural areas, Farmers Associations and Irrigation Associations. In the sense that most of these elections are hotly contested and the results not always predictable, 
'facade' might be too strong a term. In the senses that the KMT in various ways limits the range of competitors and that the elected bodies have little authority or resources, the epithet is fully justified [Clough 1978: ch 2; Jacobs 1980; Winckler 1981a,b].

From the present point of view the most significant 'managed' institutions in Taiwan are the Farmers Associations, which have been widely praised as models of democratic, participation and efficient rural institutions [K woh 1964; Stavis 1974]. While accepting that some of them have a relatively good record as agricultural service agencies, this author would emphasise: ${ }^{3}$ the tight political control exercised over the Farmers Associations; the extent to which they have been used to serve state rather than farmer interests; and the way in which they are in aggregate kept fragmented and relatively powerless. Nearly all authority and resources are concentrated at township level, and the superior (county, provincial) levels are relatively unimportant. The near absence of large and influential farmers has helped in maintaining a high degree of state control over the Farmers Associations. ${ }^{4}$

\section{'New Deals' for Agriculture}

In both Taiwan and South Korea the late 1960s saw the inception of policies which were ultimately to lead to a fundamental shift in the relationship between agriculture and the rest of the economy. Following the path beaten by Japan and other industrial nations, agriculture is now a subsidised and protected sector in both countries. This 'new deal' did not take exactly the same form in both countries. In particular, while in Taiwan it was associated with a gradual decline in the degree of direct state involvement in the agricultural economy [Moore 1983], in Korea, because the "new deal' coincided with the large scale introduction of high yielding rice varieties, it generated, in the short term, an increase in the use of administrative pressure aimed at influencing farmers' production practices. ${ }^{5}$ But in both countries the 'new deals' essentially took the form of attempts to shift terms of trade in favour of farmers, and were associated with increasingly overt political conflict over policy towards agriculture. As we shall see below, both processes were the outcome of major structural changes in the economy as a whole.

In Taiwan the 'new deal' began with the announcement in late 1969 of the Accelerated Rural Development Programme (ARDP) [Yu 1978]. Originally, a time bound programme focused in large part of big public

\footnotetext{
This interpretation is based on the author's fieldwork and de Lasson [1976].

4 The general point abour the greater ability of large farmers to challenge public policy is made by, for example, Bates [1981:126-7].

5 This increase in administrative pressures is documented by Brandt [1977]; Reed [1979]: Wade [1982, 1983]. However, as described in Moore [1984] this pressure was relaxed around the end of the 1970 s.
}

rural investments in infrastructure, credit and marketing, the ARDP has been extended indefinitely. It was also to become the symbolic vehicle for a set of changes in pricing and revenue policy which were to amount to a shift from industrial to agricultural bias: reductions in fertiliser prices initiated in 1970; reductions in rural taxes initiated in 1971; the abolition of the rice-fertiliser barter scheme in 1972; and, in response to further concern about the slow rate of growth of rice output in the early 1970s, a near doubling of the official purchase price of rice in 1974. Further increases in the official price of rice meant that by 1977 it had become a support price. Rather than delivering obligatory quotas of rice to government, farmers are privileged to sell to the state, at prices higher than those in the free market, a quota equivalent on average to about a quarter of production. Farmers Associations, whose main function had been to perform cheaply on behalf of the state the procurement, distribution and storage functions associated with public fertiliser and rice operations, are now allowed more generous margins on these activities and considerable autonomy to make and use substantial profits from a thriving credit business.

The 'new deal' for Korean farmers began in 1968 with the first of a series of increases in the government procurement prices of rice which were within a few years to take the domestic producer price well above world market prices. Allied to the introduction and rapid spread of high yielding rice varieties after 1970 , growing subsidies on fertiliser and a substantial shift of government investment to rural areas, this change in price policy resulted in a very rapid increase in rice production and in real farm incomes in the first half of the 1970s. And these improvements in the farm economy took place in the context of the Saemaul Movement for rural development, launched in late 1969 and the centrepiece of government policy and action in the early and mid 1970s [Moore 1984].

\section{The Reasons for 'New Deals'}

The immediate reasons for these 'new deals' in agricultural policy were both economic and political and, because of the similarities in economic and agrarian structure and economic performance, similar in both countries. The first was a marked slowing down of the rate of growth of agricultural output after 1964 in Korea and after 1965 - and again in the early 1970 s - in Taiwan. Although basically a surplus rice producer, Taiwan, given continued population growth and the concern for basic food self-sufficiency stimulated by its precarious international position, could not afford at that stage to take a relaxed at titude to declining agricultural growth rates. Only at the end of the 1970s was its rice surplus to become a financial embarrassment to the government. 
The second reason for the 'new deals' was an increasing awareness of the political consequences of the fact that from the mid 1960s the gap between average farm and average non-farm incomes began to widen alarmingly in both countries. In Korea this was manifested in the growth of shanty towns around Seoul. For the strong geographical concentration of industrial growth around Seoul and Pusan meant that, unlike in Taiwan, where industrial jobs were available in the countryside [Ho 1982], in Korea ex-farmers tended to vote with their feet.

In both countries the political leadership made major efforts to identify themselves with the rural population. In Taiwan the Accelerated Rural Development Programme was the brainchild of Chiang Ching-Kuo, the son of President Chiang KaiShek. Chiang Ching-Kuo, then Prime Minister and now President, identified himself with both rural people generally and with a group of politicians, many of them Taiwanese rather than Mainlanders, who claimed to represent the Taiwanese and farming interests. Unlike in earlier years, by 1970 the promotion of farming interests was seen as a viable route to political power. In Korea President Park, himself from a rural background and from his ascent to power in 1961 more responsive to rural issues than the previous leaders, made the originally and basically rural-oriented Saemaul Movement the ideological centre-piece of his rule in the 1970s. The need for such a shift in policy and ideology was illustrated in the 1971 Presidential elections, when Korean farmers departed from the post-1953 practice of rather passively voting for established incumbents and 45 per cent of all votes were cast against Park [Hahn 1975:88].

A third reason for the 'new deal', specific to Korea, was the decreasing willingness of American governments to feed urban Korea with cheap PL 480 foodgrains.

The ultimate causes behind these three sets of pressures for the 'new deals' were the economic successes of the 1960s. In both countries the fast growth of industrial productivity lay behind the growing farm-non-farm income diferences. Farm production was becoming more dependent on purchased current and fixed capital, and thus more vulnerable to the disincentive effects of adverse farmnon-farm terms of trade. And the emergence in both countries of a relative labour shortage in the mid-

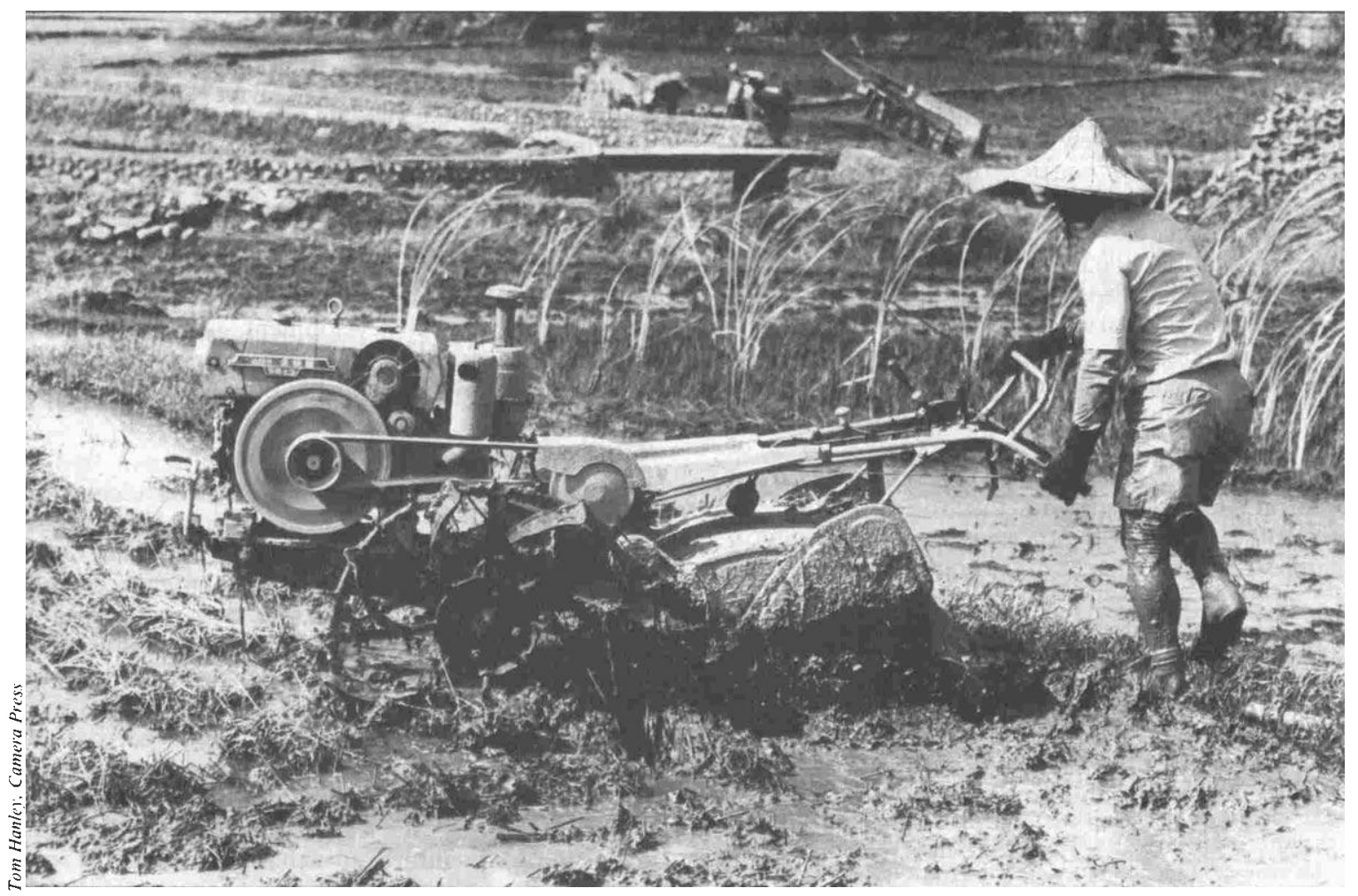

A Taivan farmer ploughs his field with a motor-driven rotovator in preparation for planting rice. 
1960s made it increasingly easy and attractive for farmers to shift family labour into non-agricultural jobs. Changes in economic structure had increased the costs to the economy of pursuing further the existing policy towards agriculture. Small farms could no longer be held 'captive' and be obliged to produce despite poor returns to farming [Moore 1984].

Economic growth and structural change were also, in a less visible fashion, changing the political equation behind the pricing policies practised in the 1950s.

In the first place, agricultural producers were becoming more specialised and marketing increased proportions of their output of the main crop, rice. The adverse effect on their incomes of the policies which had generated adverse terms of trade was becoming more visible (for specialist producers) and greater (for rice producers). Farmers were more likely to voice grievances against economic policy.

In the second place, decreasingly poor food purchasers were spending declining proportions of their incomes on food in general and basic foodgrains in particular. 'Cheap rice' was a decreasingly effective rallying point and single focus of demands, implicit or explicit, of both food consumers and industrial employers interested in cheap wage goods. ${ }^{6}$ This was especially true in somewhat wealthier Taiwan, where foodgrains feature less visibly in consumer expenditure. Korea began, and continues, to subsidise both grain producers and consumers from public funds. Taiwan continued to give cheap rice rations to public and military employees but abandoned this for all except the military in 1982, with little apparent opposition. In both countries the 'new deals' for agricultural producers were followed by real increases in consumer rice prices.

In the third place, the declining place of agriculture in national income lowered the potential cost to the government and to the economy of policies to support agriculture. Taiwan, with only eight per cent of its gross domestic product arising from agriculture in 1980 , was several years ahead of Korea, where agriculture still accounted for 20 per cent of GDP. It is fully consistent with the political and economic mechanisms posited above that during the 1970s the Taiwanese Government shifted the terms of trade more strongly in favour of farmers than did the Koreans.

\section{Contemporary Conflicts over Economic Policy}

Conflicts of interest between food producer and consumer and between agriculture and the guardians of the public purse and of the national economic

\footnotetext{
"For a description of this general process see Bates [1983:124]
}

interest did not disappear. Indeed, the latter were exacerbated by the 'new deals'. From the early 1970s the Korean Government found itself committed to very heavy subsidies on fertiliser and on the difference between the prices it paid to farmers for rice and barley and the lower prices at which it sold them to consumers. The Taiwanese Government was in a less difficult situation. For it did not subsidise fertiliser and only around the end of the 1970s did support prices for rice become a financial embarrassment, as of ficially procured rice accumulated in store and had to be exported at a loss. The financial cost to government of supporting agriculture is far lower than in Korea, although it threatens to increase now that per capita rice consumption has begun to fall rapidly, and rice prices to decline because of market forces. Government has now begun to pay farmers for not growing rice on paddy land.

In Taiwan as much as in Korea, concerns about the financial cost of supporting agriculture have been supplemented by concerns about the economic cost to the nation of protecting agriculture against competing imports. Both countries, but especially Korea, are high cost producers of grains and of some other agricultural products, including livestock products. The labour intensive small farm sector is becoming an increasing economic embarrassment. Once functional to industrial growth, it has now become a hindrance. The example of Japan, with its very heavily protected small farm sector, is a warning to both countries of the dangers of not tackling the problem seriously.

There are two main ways of attempting to deal with the agricultural problem. One is to reduce the level of agricultural protection and, making necessary allowance for the security of national food supplies, depend even more on imported grains, especially feedgrains for the fast-growing livestock sectors. Yet there are strong political arguments against such a policy. The farmnon-farm income differentials, which narrowed during the 'new deals', have begun increasing again in the late 1970s in both countries. For this and other reasons the political pressures for continuing to protect agriculture are strong in both countries.

In Taiwan the identification of farming with Taiwanese interests, although far less valid than before, is still factor to consider. And in recent years there has been a considerable 'opening up' of the higher levels of Party and government to Taiwanese politicians. They cannot easily abandon their proagriculture stances. Within the Taiwanese public bureaucracy itself agricultural protection has powerful advocates in the form of the agricultural agencies, notably the Council for Agricultural Planning and Development - formerly the Joint Sino-American Commission for Rural Reconstruction. Cynics may 
argue that the agricultural bureaucrats are motivated mainly by fear that their jobs and careers are threatened by the declining importance of agriculture. Yet the power of the agricultural bureaucracy and the Taiwanese politicians associated with it is real. In late 1983 the two managed to achieve a legislative change which will tend to increase the forces for agricultural protection.

In Korea pressures for agricultural protection are not institutionalised even to the limited degree that they are in Taiwan. The parastatal agencies serving agriculture, the National Agricultural Cooperative Federation and the new National Livestock Cooperative Federation, remain entirely state run. Attempts to turn the Saemaul Movement into something like a mass rural party to support the regime have failed, and the Movement is now virtually moribund at grass-roots levels [Moore 1984]. The main spokesmen for farmers' interests are the radical Catholic and Christian Farmers movements, which stand in complete opposition to the present regime. Although they have only a limited mass base, these movements do articulate a disillusion and resentment against government policies which is widely held in rural Korea now that the terms of trade and the weather appear to have turned against farmers since the late 1970s, the Saemaul Movement has lost its elan, and government has generally ceased to give farmers the priority and attention they commanded in the early 1970s. In recent years Korean farmers, unlike those in Taiwan, have faced a decline in the real returns to the labour they put into farming. Also unlike Taiwan, non-farm employment has not spread widely into rural areas. This currently accounts for about three quarters of farm family income in Taiwan, but only a third in Korea [Moore 1984].

The Korean Ministry of Agriculture appears well aware of the strength of rural dissent, and is itself a devout if not omnipotent advocate of protection for agriculture. Imports of some agricultural products, especially livestock products, have been liberalised in recent years [Kim and Joo 1982]. But the issue of agricultural protection is still very bitterly contested. The outcome may depend in part on the attitude taken by the large corporations which have moved into the livestock sector in a big way in recent years, and have begun, as in Taiwan, to make big inroads into the small farm livestock sector [Moore 1984]. Dependent almost entirely on feedgrain imports, and themselves often (and in Korea, increasingly) feedgrain importers, these corporations would seem to have an objective interest in liberal grain import policies and protection against imports of livestock products.

\section{Agricultural Restructuring}

As the livestock example helps to illustrate, the major restructuring of agriculture which has taken place in Taiwan and Korea has been through the market mechanisms rather than through state action. But neither government has been able to avoid exploring the second main option to solve the agricultural problem: to promote directly increases in the size of farms in both operational and ownership terms. Attempts to do this date back to the 1960s in Taiwan and the early 1970 s in Korea, with official encouragement and subsidies for cooperative farming and cooperative labour groups and farm machinery pools. The local manufacture of farm machinery has been encouraged, and retail prices subsidised. In fact little success has been attained, and the 'new deals' had an adverse effect by slowing down the rate of departure from the land. Average farm size has increased only slowly, although the rate now shows signs of speeding up. Korean governments have been prevented from taking the necessary legislative action - especially legalising tenancy, which remains formally illegal although very widespread [Moore 1984] - party through fear that raising the land issue will allow the Catholic and Christian farmers to make political capital out of such issues as suburban land speculation. The land law question has however been deemed urgent for more than a decade.

The Taiwanese Government has not been similarly constrained, and has introduced a series of measures -including special lines of credit and encouragement for farmers to reverse tradition and leave land only to a single heir - aimed at increasing the size of the land ownership unit. Such measures, along with the payment of subsidies to farmers not to grow rice on paddy land, and increasing official pressures on Irrigation Associations to 'encourage' farmers not to grow rice, illustrate that the state has felt unable to stand back and allow market forces to achieve agricultural restructuring within a reasonable time scale. Such 'market induced' restructuring is especially unlikely in Taiwan because of the widespread dispersal of industry into rural areas and the consequent high speculative value of land which might at some stage be used for industrial or housing purposes. Average farm size has tended to increase even less slowly than in Korea. One set of market forces is working directly against restructuring. Korea does not face this problem to the same degree. But because of the dearth of rural non-agricultural jobs the government has felt obliged to introduce a major programme to move industry into rural areas.

\section{Conclusion}

This article is not intended to eulogise state regulation of the agricultural economy. Many government policies and mechanisms - notably perhaps the Farmers' Associations in Taiwan - have been much 
less effective than is claimed. It is also the market rather than public action which has been the main cause of structural change in Taiwanese and Korean agriculture. The limited success of official measures to increase farm size has been mentioned. The main effective mechanism has probably been tenancy arrangements which have been, and in Korea remain, formally illegal. In Taiwan failure to legalise new tenancy arrangements until 1983, a product of attachment to institutionalised myths about the liberating role of the Nationalists' land reforms of the late 1940s and early 1950s, have often been cited by farmers as an obstâcle to greater recourse to leasing of land. It is mainly the market which is responsible for the big shift of Taiwanese and Korean agriculture away from cereals to horticultural and livestock products [Moore 1983]. This was in part the result of policies which depressed cereal prices [Kuo 1983:ch 3], but was contrary to the intentions and declared policy of government. The gver-promotion in Korea of new rice varieties, which proved very susceptible to disease and poor weather in the later 1970s [Moore 1984], is the clearest example of misguided public actions in the agricultural sphere

Yet it would be doctrinaire in the extreme to cite such examples of ineffective or inefficient state action as evidence to support the case of minimal state intervention. There is every reason to believe that the policies to 'squeeze' agriculture in the 1950s and 1960s did make an important contribution to fast industrial growth. It is difficult to believe that agricultural production would have grown much faster in the long term if it had not been the 'victim' of these policies. The long term agricultural production growth rate of 3.7 per cent per year which has been achieved in both countries since the mid-1950s is itself impressive in the global context. It owes a great deal to the rapid growth of consumer demand for horticultural and livestock products which industrial growth engendered. Without this new consumer demand for high value, labour intensive, land saving products, Taiwanese and Korean farmers would have been 'trapped' at lower income levels into dependence on relatively land intensive cereal production in a situation where land is extremely scarce.

Perhaps even more importantly, the case material here illustrates the impracticability of the doctrine of minimal state intervention in the economy. Firstly, the need to restructure the economy to cope with the problems engendered by economic growth forces the state to take a hand. Secondly and perhaps more importantly, changes in economic structure oblige the state to intervene in the economy in new ways in order to maintain the political support or acquiescence of the population. The ultimate weakness of extreme doctrines of laisser faire is that they abstract totally from politics. Political order, with all the implications it has for investor confidence in 'open' capitalist economies, must be an objective of a viable economic policy.

\section{References}

Aqua, R., 1974, Local Institutions and Rural Development in South Korea, Cornell University Rural Development Committee, Ithaca

Ban, S. H. et al, 1980, Studies in the Modernisation of the Republic of Korea: 1945-75. Rural Development, Harvard University Press, Cambridge (Mass) and London

Bates, R., 1981, Markets and States in Tropical Africa: the political basis of agricultural policies, University of California Press, Berkeley

-1983, Essays on the Political Economy of Rural Africa, Cambridge University Press

Brandt, V., 1977, 'Why rural Korea was transformed', The Asia Wall Street Journal, 14 January

Clough, R., 1978, Island China, Harvard University Press, Cambridge (Mass)

de Lasson, A., 1976, The Farmers' Association Approach 10 Rural Development - the Taiwan case, Sozialekonomische Schriften zur Agraventwicklung no 19, Verlag der SSIPSchriften, Saarbrucken

Hahn, K. S., 1975, 'Underlying factors in political party organisation and elections" in E. R. Wright (ed), Korean Politics in Transition, University of Washington Press, Seattle and London

Ho, S. P. S., 1982, 'Economic development and rural industry in South Korea and Taiwan', World Development, vol 10 no 11

Hofheinz, R. and K. E. Calder, 1982, The East Asia Edge, Basic Books, New York

Jacobs, B. J., 1980, Local Politics in a Rural Chinese Cultural Setting: a field study of Mazu lownship, Taiwan, Contemporary China Centre, Australian National University, Canberra

Johnston, B. F. and W. C. Clark, 1982, Redesigning Rural Development: a strategic perspective, Johns Hopkins University Press, Baltimore

Kim, D. H. and Y. J. Joo, 1982, The Food Situation and Policies in the Republic of Korea, Development Centre, OECD, Paris

Kuo, S. W. Y., 1983, The Taiwan Economy in Transition, Westview Press, Boulder (Co)

Kwoh, M. H., 1964, Farmer's Associations and their Contributions towards Agricultural and Rural Development in Taiwan, FAO, Bangkok 
Lee, T. H., 1971, Intersectoral Capital Flow's in the Economic Development of Taiwan 1895-1960, Cornell University Press, London and lthaca

Moore, M., 1983, 'The softening state? Capitalist industrialisation and smallholder farming in East Asia (Taiwan and South Korea)', paper presented to the Conference of the Development Studies Association, held at the Institute of Development Studies, Sussex, September

-1984, 'Mobilisation and disillusion in rural Korea: the Saemaul Movement in retrospect', 1nstitute of Development Studies, Sussex, mimeo

Reed, E., 1979, Group farming in smallholder agriculture: experience and potential in South Korea, PhD thesis, University of Wisconsin, Madison

Stavis, B., 1974, Rural Local Governance and Agricultural Development in Taivan, Cornell Rural Development Committee, lthaca
Thorbecke, E., 1979, 'Agricultural development' in W. Galenson (ed), Economic Grow'th and Structural Change in Taiwan, Cornell University Press, lthaca

Wade, R., 1982, Irrigation and Agricultural Politics in South Korea, Westview Press, Boulder (Co)

-1983, 'South Korea's agricultural development: the myth of the passive state', Pacific Viewpoint no 24

Winckler, E. A., 1981 a, 'National, regional and local politics' and

$-1981 \mathrm{~b}$, 'Roles linking state and society' in Ahern and H Gates (eds), The Anthropology of Taiwanese Society, Stanford University Press

Yu, T. Y. H., 1978, 'The accelerated rural development program in Taiwan' in Agricultural Economic Research Papers, Economic Digest Series no 23, Joint Commission on Rural Reconstruction, Taipei 